\title{
MELEJITKAN LINGUISTIC INTELEGENCE MELALUI GEMAR MEMBACA
}

\author{
Muzdalifah M Rahman
}

Jurusan Tarbiyah STAIN Kudus

\begin{abstract}
Linguistic Intelligence, a person's ability and sensitivity to interpret the wording, is able to use words effectively, both orally and in writing. Intelligence of this type are identified by Gardner much involved in reading, writing, speaking, and listening.
\end{abstract}

Reading ability is influenced by several factors, including 1) fluency in reading, 2) the ability to hear, 3) the ability to see, 4) environmental influences, 5) emotional factors, and 6) the child's intelligence.

Some of these factors so as to be an influence in the child's reading ability, therefore, in this case the reading ability of emotion is always enhanced by a variety of ways, as for how that can be achieved are: 1) read children books from birth, 2) encourage children to talk about what has been heard or read, 3) taking children to the bookstore or library, 4) purchase books that attract children, 5) set aside the money to buy books for children, 6) to set aside money to buy books for children, 7) watch movies as well as buy books according to the film, 8) creates a family library at home, 9) exchange of books belonging to the child by his friend, 10) removes inhibitors such as TV and Playstation, 11) to give the reward to enlarge the spirit of reading child, 12) to make the book as a reward for kids, 13) make reading a daily activity, 14) to dramatize the contents of the book that was read to the child, and 15) make their own books.

Keywords: linguistic intelegence, membaca

\section{Pendahuluan}

Kebiasaan membaca dan menulis anak-anak Indonesia bisa dibilang sangat rendah, tidak perlu jauh menelisik pada anak-anak di negara Eropa seperti Inggris, Prancis, Amerika, bahkan Jerman, di kawasan Asia Tenggara (ASEAN) saja, kebiasaan membaca dan menulis juga tergolong sangat rendah. 
Pasalnya Indonesia berdasakan studi lima tahunan yang dikeluarkan oleh Progress in International Reading Litercy Study (PIRLS) pada tahun 2006 yang melibatkan siswa SD hanya menempatkan Indonesia pada posisi ke 36 dari 40 negara yang dijadikan sampel penelitian. (Republika.co.id).

Sementara itu berdasakan penelitian Human Developmen Index (HDI) yang dikeluarkan oleh UNDP pada tahun 2002 menetapkan bahwa Indonesia pada posisi 110 dari 173 negara. Posisi tersebut kemudian turun satu tingkat menjadi 111 di tahun 2009. (Republika.co.id).

Kemudian menurut data UNESCO (Unaited National Education, Scientific and Cultural Organization $)^{1}$ tahun 2012 index minimal membaca penduduk Indoensia hanya 0,0001\%, yang berarti dari 1.000 penduduk Indonesia hanya ada 1 orang yang membaca buku. ${ }^{2}$ Sedangkan rata-rata index tingkat membaca di negara maju berkisar antara $0,45 \%$ hingga $0,62 \%$. Kondisi ini sehingga menempatkan Indonesia pada posisi ke 124 dari 187 negara dalam Index Pembangunan Manusia (IPM) pada tahun 2012. (Republika.co.id).

Data-data tersebut tampaknya akan semakin memburuk mengingat minimnya infrastruktur serta perhatian yang ada pada saat ini. Pasalnya kebiasaan anak dalam membaca biasanya dikaitkan dengan keberadaan perpustakaan yang disediakan oleh lembaga pendidikan atau lembagalembaga tertentu, sementara fasilitas perpustakaan untuk dekade terahir ini bisa dibilang belum sebanding dengan jumlah penduduk Indonesia. Sebagaimana yang dilansir oleh Perpustakaan Nasional Republik Indonesia, bahwa jumlah perpustakaan sekolah di Indonesia berjumlah 177.000 perpustakaan dengan total koleksi 106 juta buku, dan 798 perpustakaan khusus, sedangkan perpustakaan yang disediakan pada masyarakat umum hanya 2.583 perpustakaan. Selain terbatasnya fasilitas perpustakaan, jumlah ketersediaan buku di Indonesia juga bisa dibilang terbatas, jika dibandingkan dengan Cina yang jumlah penduduk 1,3 milyar mampu menerbitkan buku 140.000 judul buku baru dalam setiap tahun, Vietnam dengan 80 juta jiwa mampu menerbitkan 15.000 judul buku baru per tahun, kemudian Malaysia yang berpenduduk 26 juta jiwa menerbitkan 10.000

1 Organisasi Pendidikan, Keilmuan, dan Kebudayaan PBB merupakan badan khusus $\varangle$ PBB pyang didirikan pada 1945 tujuan organisasi ini adalah mendukung perdamaian, dan F keamanan dengan mempromosikan kerjasama antara negara melalui pendidikan, ilmu pengetahuan, dan budaya dalam rangka meningkatkanrasa saling menghormati yang berlandaskan pada keadilan, peraturan hukum, HAM, dan kebebasan hakiki. (Pasal 1 Konstitusi UNESCO). Id.wikipedia.org/wiki/Organisasi-pendidikan-keilmuan-dan kebudayaan. 
judul, sementara Indonesia yang berpenduduk sekitar 225 juta jiwa hanya mampu menerbitkan 10.000 judul buku baru dalam satu tahun. (Perpusnas. go.id).

Sementara data Badan Pusat Statistik (BPS) menunjukkan bahwa penduduk di Indonesia belum menjadikan membaca sebagai informasi, sementar penduduk lebih memilih menonton televisi dan mendengarkan radio, bahkan kecenderungan cara mendapatkan informasi lewat membaca masih stagnan sejak tahun 1993 dan hanya naik 0,2\%, jauh jika dibandingkan menonton TV yang kenaikan presentasinya mencapai 211,1\%. (Perpusnas. go.id).

Terlepas dari jumlah perpustakaan, jumlah buku yang dapat dipublikasikan, dan kebiasaan dalam memperoleh informasi, yang perlu untuk ditanamkan sedari dini kepada anak-anak Indonesia adalah pemahaman serta kesadaran mengenai kebiasaan membaca buku, yang sebenarnya kebiasaan tersebut mampu membawa pada perubahan besar. Sebab ada istilah membaca buku merupakan jendela dunia, dengan membaca anak mampu memahami gambaran umum baik itu dari segi sosiologis, agama, suku, budaya dan ekonomi suatu daerah tanpa menjelejah secara langsung, dengan demikian membaca buku juga mampu merubah keadaan menjadi lebih baik, karena tidak jarang kita temui seseorang yang mampu berubah kehidupannya karena terinspirasi oleh kata-kata yang terkandung dalam buku yang dibacanya, dan yang lebih penting bahwa membaca buku dapat meningkatkan kosakata, serta mengasah kemampuan menulis, atau sering disebut sebagai linguistic intelegence.

Seperti halnya kisah dari Putu Putra Yasa seorang penulis, yang saat ini menjadi pengusaha dan memimpin Harian BERNAS, ia mengaku hidupnya telah berubah menjadi lebih baik, setelah gemar membaca bukubuku inspiratif seperti buku "Berpikir dan Berjiwa Besar" karya Dr. David J. Schwart.

Melihat manfaat yang ditimbulkan melalui kebiasaan membaca buku seperti halnya kisah di atas setidakya menjadi cambuk dalam meningkatkan semangat membaca anak-anak Indonesia. Oleh karena itu disini perlu adanya perhatian secara khusus dari sisi psikologis dan sosiologis yaitu peran orang tua, masyarakat, lembaga pendidikan, dan pemerintah sekalipun untuk terus gencar menanamkan habit membaca buku kepada anak-anak Indonesia, supaya linguistic intelegnce nya semakin meningkat serta mampu memberi perubahan yang berarti.

Untuk menciptakan kebiasaan membaca pada anak dapat dimulai dari 
sedini mungkin, dan dapat dilakukan pada lingkungan keluarga sendiri, maka dari itu disini peran orang tua menjadi sangat fundamental mengajarkan serta membiasakan anak untuk membaca buku dengan berbagai macam cara, seperti memberikan reward kepada anak yang membaca buku, mengajak ke toko buku dan perpustakaan, dan cara-cara lainnya yang akan dikupas dalam pembahasan berikut.

\section{Metode Penulisan}

Penulisan ini menggunakan metode qualitative research. Dalam pengumpulan data-data dalam penelitian ini penulis menggunakan studi kepustakaan (library research), dengan merujuk kepada artikel, bukubuku, internet, dan berita-berita media yang relevan. Dalam pengumpulan data-data tersebut penulis lebih mengacu kepada data-data dari internet dan buku-buku, karena keterbatasan penulis dalam mencari data-data yang original.

\section{Pembahasan}

\subsection{Inteligensi}

Spearman \& Wynn Jones, 1951 dalam buku mereka yang berjudul Human Ability, mengumakakan adanya suatu konsepsi lama mengenai suatu kekuatan (power) yang dapat melengkapi akal pikiran manusia dengan gagasan abstrak yang universal, untuk dijadikan sumber tunggal pengetahuan sejati. Kekuatan demikian dalam bahasa Yunani disebut dengan istilah nous, sedangkan penggunaan kekuatan termaksud disebut dengan noises. Kemudian kedua istilah tersebut dalam bahasa Latin dikenal sebagai intelectus dan intelligentia. yang pada gilirannya, dalam bahasa Inggris masing-masing kata tersebut diterjemahkan sebagai intelect dan intelligence. Ternyata, dalam transisi asal kata tersebut membawa pada perubahan makna. Intelligence, yang dalam bahasa Indonesia kita sebut inteligensi, semula berarti penggunaan kekuatan intelektual secara nyata, akan tetapi di dalam bahasa Indonesia kemudian diartikan sebagai suatu kekuatan lain.

Menurut kamus ilmiah populer kata "intelegensi" bersal data kata “intelegen" yang bermakna tajam pikiran, cerdas, cerdik, cendekia, bijaksana. Sementara intelegensi sendiri dimaknai sebagai kecerdasan atau ketajaman pikiran. (Pius Partanto 2001; 270).

Pemaparan diatas berimplikasi bahwa yang dimaksud dengan 138 intelegensi merupakan suatu kemampuan yang dimiliki seseorang dalam 
memaknai suatu objek tertentu, yang dapat difungsikan sebagai panduan dalam melakukan sesuatu.

\subsection{Kecerdasan Berbahasa (Linguistic Intelegence)}

Kalau kita memahami induk kucing dengan anak-anaknya, sering kali kita melihat dan mendengarkan sang induk mengeluarkan bunyibunyi tertentu dan dalam waktu sekejap anak-anaknya akan berlari dan menghampiri induknya, setelah kita memperhatikan ternyata sang induk kucing tersebut sedang memberitahukan kepada anak-anaknya bahwa di sekitarnya ada suatu bahaya.

Kemudian pada kera yang hidup berkelompok di suatu hutan, akan mengeluarkan bunyi-bunyi tertentu kepada sekawanan kera lainnya untuk memberitahukan bahwa di suatu tempat ada buah-buahan yang banyak.

Dari dua contoh di atas menunjukkan bahwa antara kucing dan kera mempunyai kemampuan untuk berkomunikasi dengan anak maupun temannya dengan mengeluarkan bunyi-bunyi yang dikeluarkan oleh keduanya.

Begitu juga manusia, manusia juga dapat dengan mudah berkomunikasi dengan teman-teman dan menggunakan bahasa, yang menjadi pertanyaan apakah bahasa yang dipakai oleh binatang adalah sama dengan bahasa yang dipakai oleh manusia? meskipun disatu sisi ada ada persamaan, namun di sisi yang lain ada perbedaan antara bahasa yang digunakan oleh binatang dengan bahasa yang digunakan oleh manusia, diantaranya bahasa yang digunakan oleh manusia memiliki ketergantungan struktur (strukture dependence), bahasa dan pemakaian bahasa cenderung kreatif, bahasa manusia dapat digunakan untuk mengungkapkan situasi atau peristiwa yang sudah lampau atau yang belum terjadi dan bahkan untuk sesuatu yang dibayangkan, bahasa manusia memiliki struktur ganda yang dinamakan struktur batin (deep structure) dan struktur lahir (surface structure), bahasa manusia diperoleh secara turun-temurun dari satu generasi ke generasi yang lain, hubungan antara kata dengan benda, perbuatan, atau keadaan yang dirujuknya itu arbitrer (arbitrary), bahasa manusia memiliki pula dualitas, artinya bunyibunyi itu sendiri sebenarnya tidak mempunyai makna dan baru bermakna setelah bunyi-bunyi itu diganbungkan, bahasa manusia memiliki semnatitas artinya bahwa begitu suatu nama diberikan maka nama itu akan selalu merujuk pada konsep itu, meskipun benda itu sebenarnya tidak memenuhi syarat untuk nama itu. (Soenjono Dardjowidjojo 2012; 10-15).

Menurut data diatas sehingga bahasa bisa didefinisikan dari pelbagai 139 
sudut pandang, namun di sini definisi tentang bahasa yang banyak dipakai adalah suatu sistem simbol lisan yang arbitrer yang dipakai oleh anggota suatu masyarakat untuk berkomunikasi dan berinteraksi antar sesamanya, berlandaskan pada budaya yang mereka miliki bersama. (Soenjono Dardjowidjojo 2012; 16).

Sementara Soeparno dalam bukunya berpendapat bahwa linguistic merupakan disiplin ilmu yang mempelajari bahasa secara luas dan umum. secara luas berarti cakupannya meliputi semua aspek dan komponen bahasa. Secara umum berarti sasarannya tidak hanya terbatas pada salah satu bahasa saja (misalnya bahasa Indonesia saja). (Soeparno 2002; 21).

Soeparno juga menjelaskan bahwa suatu bahasa yang dipakai oleh manusia sebenarnya memiliki beberapa fungsi dalam penggunaanya baik secara umum mapun secara khusus.

Fungsi bahasa secara umum adalah sebagai alat komunikasi sosial. Di dalam masyarakat ada komunikasi atau saling hubungan antar anggota. Untuk keperluan itu dipergunakan suatu wahana yang dinamakan bahasa. Dengan demikian setiap masyarakat dipastikan memiliki dan menggunkan alat komunikasi sosial tersebut. Karena tidak ada masyarakat tanpa bahasa dan tidak ada pula bahasa tanpa masyarakat. (Soeparno 2002; 5).

Sementara fungsi bahasa secara khusus adalah sebagai fungsi emotif, konatif, referensial, puitik, fatik, dan metaligual. Fungsi emotif apabila tumpuan pembicaraan pada konteks (context), fungsi bahasanya disebut referensial. Apabila tumpuan pembicaraan pada amanat (message), fungsi bahasanya puitik (poetic). Apabila tumpuan pembicaraan pada konteks (contact), fungsi bahasanya disebut fatik (phatic). Apabila tumpuan pembicaraan pada kode (code), fungsi bahasanya disebut matalingual. Apabila tumpuan pembicaraan pada lawan bicara (addresce), fungsi bahasanya dinamakan konatif.

Fungsi emotif misalnya dipakai apabila kita mengungkapkan rasa gembira, kesal, sedih, dan sebagainya. jika kita membicarakan suatu permasalahan dengan topik tertentu maka hal tersebut tercakup di dalam fungsi referensial. Jika kita menyampaikan suatu amanat atau pesan tertentu fungsi bahasa yang terlibat adalah fungsi puitik. Selanjutnya apabila kita di dalam berbicara sekedar ingin mengadakan kontak dengan orang lain, maka fungsi bahasa yang terlibat adalah fungsi fatik. Orang Jawa apabila berpapasan dengan orang yang sudah kita kenal baik maka selalu menggunakan fungsi fatik ini, dengan mengucapkan: "Mangga!" atau dengan kalimat tanya "Badhe 140 tindak pundi?" yang kesemuanya itu tidak maksud lain kecuali sebagai alat 
kontak semata. Orang Belanda menggunakan ucapan "Dag!" untuk tujuan yang sama seperti diatas.

Kemudian apabila kita berbicara masalah bahasa dengan menggunakan bahasa tertentu, maka fungsi bahasa disitu adalah matilingual. Selanjutnya apabila kita berbicara atau berbahasa dengan tumpuan pada lawan tutur, misalnya agar lawan bicara kita bersikap atau berbuat sesuatu, maka fungsi bahasa tersebut yang digunakan adalah konatif. (Soeparno 2002; 8).

Sementara Dell Hymes mengembangkan fungsi-fungsi bahasa yang pada prisnispnya merupakan rincian dari fungsi bahasa yang telah dikemukakan di atas, diantaranya :

1. Untuk menyesuaikan diri dengan norma-norma sosial. Misalnya, untuk menulis surat lamaran, untuk mengajukan permohonan, untuk meminta ijin, dan sebagainya.

2. Untuk menyampaikan pengalaman tentang keindahan, kebaikan, keluhuran budi, keagungan, dan sebagainya.

3. Untuk mengatur kontak sosial, misalnya untuk tegur sapa, gretting, salam, dan sebagainya. (Soeparno 2002; 9).

Sebagai pendukung dalam hal ini Gardner juga merumuskan teori Inteligensi Ganda (multiple intelligence) yang didorong oleh pendapatnya bahwa pandangan dari sisi psikometri dan kognitif saja terlalu sempit untuk menggambarkan konsep inteligensi. Pendekatan teori Gardner sangat berorientasi pada struktur inteligensi yang salah satunya berbicara mengenai linguistik.

Dalam usahanya melakukan identifikasi terhadap inteligensi, Gardner menggunakan beberapa macam kriteria, yaitu (a) pengetahuan mengenai perkembangan individu yang normal dan yang superior, (b) informasi mengenai kerusakan otak, (c) studi mengenai orang-orang eksepsional seperti individu yang luar biasa pintar, juga individu idiot savant, dan orang-orang autistik, (d) data psikometrik, dan (e) studi pelatihan psikologis. Gardner mengatakan bahwa berbagai inteligensi yang telah diidentifikasikannya bersifat universal sekalipun secara budaya tampak berbeda. Sebagai contoh, inteligensi linguistik tidak selalu dinyatakan dalam bentuk tulisan tergantung pada budaya mana yang diperhatikan. Inteligensi sangat banyak ragamnya dan kebanyakan bersifat kognitif. Berikut tujuh macam inteligensi yang telah berhasil diidentifikasikan oleh Gardner yaitu: Inteligensi Matematik-logis, Inteligensi Spatial, Inteligensi Musik, Inteligensi Kelincahan Tubuh, Inteligensi Interpersonal, Inteligensi Intrapersonal, dan Inteligensi Linguistik. 
Dari beberapa hasil identifikasi intelegensi menurut Gardner mempunyai fungsi dan peranannya masing-masing berikut penjelasannya : Pertama, Inteligensi matematik-logis adalah inteligensi yang digunakan untuk memecahkan problem berbentuk logika simbolis dan matematika abstrak.

Kedua, Inteligensi spatial digunakan dalam mencari cara untuk berpindah dari satu tempat ke tempat yang lain, untuk mengatur isi koper agar memuat barang-barang dengan efisien, membayangkan langkahlangkah lanjutan dalam permainan catur, dan semacamnya. Belahan otak sebelah kanan merupakan sumber inteligensi ini. Sehingga kalau terjadi kerusakan disana maka proses spatial akan terganggu.

Ketiga, Inteligensi musik berfungsi dalam menyusun lagu, menyanyi, memainkan alat musik, ataupun sekedar mendengarkan musik. Sekalipun belahan otak sebelah kanan banyak mengandung inteligensi musik, menurut Gardner, inteligensi musik tidak terlalu pasti letaknya.

Keempat, Inteligensi kelincahan tubuh diperlukan dalam aktivitasaktivitas atletik, menari, berjalan, dan semacamnya. Kendali gerak tubuh terletak pada bagian korteks gerak di otak yang sisi-sisinya mengendalikan gerakan bagian tubuh pada sisi yang berlawanan.

Kelima, Inteligensi interpersonal digunakan dalam berkomunikasi, saling memahami, dan berinteraksi dengan orang lain. Orang yang tinggi inteligensi interpersonalnya adalah mereka yang memperhatikan perbedaan diantara orang lain, dan dengan cermat dapat mengamati temperamen, suasana hati, motif, dan niat mereka. Inteligensi ini sangat penting pada pekerjaan-pekerjaan yang melibatkan orang lain seperti ahli psikoterapi, guru, polisi dan semacamnya.

Keenam, Inteligensi intrapersonal sangat dibutuhkan dalam memahami diri sendiri. Merupakan kepekaan seseorang akan suasana hati dan kecakapannya sendiri.

Ketujuh, Inteligensi linguistik, merupakan kemampuan dan kepekaan seseorang dalam memaknai susunan kata, mampu menggunakan kata secara efektif, baik secara lisan maupun tertulis. Intelegensi pada jenis ini diidentifikasi oleh Gardner banyak terlibat dalam kegiatan membaca, $\varangle$ menulis, berbicara, dan mendengar.

Masih enurut Gardner, aktivitas linguistik terletak pada bagian tertentu dalam otak. Sebagai contoh, daerah Broca adalah lokasi terjadinya kalimatkalimat yang sesuai dengan struktur bahasa sehingga seseorang yang 142 mengalami kerusakan pada daerah tersebut, sekalipun dapat memahami 
kata dan kalimat, akan tetapi sulit merangkainya menjadi kalimat yang benar.

Intelegensi linguistik sendiri mempunyai tujuan. Pertama, anak mampu membaca serta memahami apa yang telah ia baca, kedua, anak mampu mendengarkan dengan baik serta mampu memberikan respon berbentuk komunikasi secara lisan, ketiga, anak mampu menirukan suara, mampu mempelajarai bahasa asing, dan mampu membaca karya orang lain, keempat, anak mampu menulis dan berbicara secara efektif dan tertarik pada karya-karya jurnalistik, berdiplomasi, mampu bercerita, serta melakukan kegiatan editing pada karya tulis orang lain, kelima, mampu belajar melalui apa yang ia dengar, tulisan, dan berdiskusi.

\subsection{Ketrampilan Membaca Anak}

Ketrampilan berbahasa meliputi empat aspek, yaitu: ketrampilan menyimak atau mendengarkan, ketrampilan berbicara, ketrampilan membaca, dan ketrampilan menulis. (Guntur Targan. 2008; 1) Salah satu upaya mengembangkan kecerdasan berbahasa adalah dengan cara meningkatkan kegemaran membaca.

Menurut Hodgson dalam Henri Guntur Targan dalam bukunya mendifinisikan membaca sebagai suatu proses yang dilakukan serta dipergunakan oleh pembaca untuk memperoleh pesan yang hendak disampaikan oleh penulis melalui media kata-kata atau bahasa tulis. Suatu proses yang menuntur agar kelompok kata yang merupakan satu kesatuan akan terlihat dalam pandangan sekilas dan makna kata-kata secara individual akan dapat diketahui. Jika ini tidak terpenuhi pesan tidak akan tertangkap dan proses membaca tidak terlaksana dengan baik ( Hodgson 1960; 43-44).

Sementara dari segi lingustik membaca merupakan suatu proses penyandian kembali, dan pembacaan sandi. Sebuah aspek penyandian adalah menghubungkan kata-kata tulis dengan makna bahasa lisan yang mencakup pengubahan tulisan atau cetakan menjadi bunyi yang bermakna (Anderson 1972; 209-210).

Faktor-faktor yang mempengaruhi perkembangan bahasa dan pemikiran anak sangat tergantung pada kemampuan setiap individu. Kemampuan atau ketrampilan itu antara lain:

a. Fasih dalam membaca

Setelah anak dapat membaca dengan lancar, maka memanfaatkan kemampuannya untuk menjelaskan arti kalimat dan memahami susunannya. Seiring dengan penguasaan kosakatanya yang bertambah, maka ia akan dapat memahami bacaannya. 
b. Kemampuan mendengar

Mendengar merupakan langkah awal dalam belajar bahasa dan suara, serta hubungan antara pembicaraan dan bacaan secara jelas. Tidak dapat mendengar dengan baik anak akan kesulitan dalam membedakan antra suara yang didengar dengan kalimat yang dilihat dan dibacanya.

c. Kemampuan melihat

Penglihatan yang kurang baik dapat menyebabkan penglihatannya terhadap kalimat bergoyang atau berubah dari bentuk aslinya, sehingga akan mengganggu kemampuan membaca. Penglihatan semua anak sama namun berbeda dalam hal kematangannnya. Kematangan penglihatan anak tergantung pada tingkat kematangan masing-masing anak.

d. Pengaruh lingkungan

Iklim rumah yang sehat dapat membantu pertumbuhan bahasa anak, sebab dalam kondisi yang baik anak dapat berkomunikasi dengan orang tuanya, berdiskusi, dan orang tuanya juga menjawab pertanyaan yang diajukan oleh anak-anaknya.

e. Faktor emosi

Yang dimaksud dengan faktor emosi menurut penulis bagian dari aspek psikologis yang mempengaruhi aktvitas belajar membaca pada anak yaitu konsentrasi, minat, gangguan kemampuan membaca seperti kesulitan dalam pengucapan, perasaan malu dan masalah emosi yang belum matang.

f. Kecerdasan

Kecerdasan berpengaruh pada kemampuan membaca. Banyak penelitian menunjukkan bahwa keterlambatan anak membaca disebaban oleh tingkat kecerdasannya yang rendah. (Fahim Musthafa. 2005; 57-60).

Dari pemaparan diatas sehingga berimplikasi bahwa lingusitik intelegensi sebenarnya tidak dimiliki oleh setiap anak, karena linguistik intelegensi sendiri dapat dipengaruhi oleh beberapa faktor diatas, serta linguistik intelegensi yang sudah dimiliki oleh anak juga perlu adanya pemeliharaan bahkan peningkatan untuk tetep meningkatkan linguistik intelegensi tersebut.

3.4 Meningkatkan Gemar Membaca pada Anak

Pada umumnya anak cenderung ingin mengetahui banyak hal dan kecenderungannya pun beragam. Idealnya membaca memiliki peran mendasar dalam menjawab pertanyaan di benak anak. Sehingga pada 
pendidik maupun orang tua harus memahami kecenderungan anak pada setiap fase, usia, dan tigkat sekolah, sehinggga bisa diharapkan anak akan membaca dengan perasaaan senang.( Fahim Musthafa. 2005; 85-86).

Beberapa penelitian tentang kegemaran membaca menetapkan hasil temuan bahwa ;

a. Usia dan jenis kelamin (laki-laki atau perempuan) mempengaruhi anak memilih materi bacaan

b. Kecerdasan, kondisi keluarga, dan ketrampilan membaca merupakan faktor-faktor yang mempengaruhi anak dalam memilih bacaannya

c. Anak yang berusia enam atau tujuh tahun lebih menyukai cerita-cerita tentang hewan , kisah-kisah fiksi, humor, kepahlawanan dan petualangan. ( Fahim Musthafa. 2005; 86).

Untuk membentuk iklim gemar membaca yang konsisten di tengahtengah keluarga, maka orang tua senantiasa melakukan kegiatan-kegiatan yang bernilai bagi anak, sehingga tercipta lingkungan membaca yang kondusif. Dengan begitu, anak akan menghabiskan waktu mereka dengan membaca dan belajar.

Berikut ini upaya yang dapat dilakukan orang tua dalam menumbuhkan kegemaran membaca anak, antara lain :

a. Bacakan buku sejak lahir

Menurut Doktor Glenn Doman bahwa ketrampilan membaca sudah dapat diajarkan sejak bayi. Sejak bayi atau sejak dalam kandungan lebih baik dibiasakan membaca. Berdasarkan penelitian bahwa janin dalam kandungan sudah mampu mendengar suara ayah dan ibunya. Hal in terbukti dengan adanya teori perlunya bayi di dalam kandungan mendengarkan musik Mozart. Dengan membacakan buku untuk anak sejak dalam kandungan, orang tua sebenarnya sudah membangaun jalinan emosi dengan bayinya.

Kebiasaan yang dilakukan orang tua membacakan atau menceritakan buku sebiknya terus berlanjut pada usia 2 sampai 3 tahun yang kadang-kadang masih sehingga tidak mau duduk untuk mendengarkan. Walaupun anak tidak mau duduk orang tua terus membacakan atau bercerita sambil bermain karena yang penting anak mendengar. Menanamkan kegemaran atau minat membaca harus terus menerus di lakukan.

Membacakan buku kepada anak sedari masih dalam kandungan sampai ia mampu membaca buku untuk dirinya sendiri sebetulnya untuk menumbuhkan habit agar anak nantinya ketika sudah dewasa 
mampu secara rutin dan terbisa membaca buku dibanding dengan melakukan kegiatan yang lainnya seperti menonton TV, plastaison dan lain sebagainya.

b. Mendorong anak bercerita tentang apa yang telah didengar atau dibacanya

Anak-anak menjadi antusias ketika orang tua mengajak berdiskusi tentang apa saja yang baru diceritaan atau tentang buku yang baru dibacakan oleh orag tuanya. Selain itu orang tua bisa memancing anak untuk bercerita dengan pengajuan pertanyaan-pertanyaan dan meminta bercerita kembali isi buku secara keseluruhan.

c. Mengajak anak ke toko buku atau perpustakaan

Membiasakan untuk mengajak anak ke toko buku dan membiarkan memilih sendiri buku yang diminati anak tetapi dengan batas-batas seleksi orang tua, jangan sampai anak membeli komik-komik dengan tema kekerasan atau buku lainnya yang merusak perkembangan anak. Jadi menenemkan sejak dini kepada anak agar selektif dalam memilih buku bacaan.

Selain itu orang tua mendorong anaknya untuk rajin meminjam buku di perpustakaan mana saja yang bisa dikunjungi baik di perpustakaan sekolah atau di perpustakaan -perpustakaan lain yang bisa dikunjungi. Manfaat dari seringnya mengunjungi perpustakaan, anak akan menjadi kaya bacaan dengan biaya murah dan dengan keterlibatan anak sejak dini di perpustakaan akan sangat berguna bagi belajarnya nanti di waktu dewasa.

d. Membeli buku yang menarik minat anak

Orang tua berusaha memilihkan buku bacaan yang bermutu bagi anak, tetapi harus juga emperhatikan apakah buku yang dibeli itu menarik menurut anak. Jika buku tersebut bermutu namun kurang menarik menurut, sebaiknya orang tidak memaksakannya untuk membaca. Jadi tugas orang tua adalah mempengaruhi anak supaya tertarik tetapi jangan memaksakan secara terang-terangan supaya minat bacanya tidak menurun.

e. Menyisihkan uang untuk membeli buku

Jika orang tua menganggap buku itu penting untuk anak, maka orang tua seyogyanya membuat angggaran bulanan untuk membeli buku. Dalam menyisihkan uang untuk membeli buku setidaknya disesuaikan dengan penghasilan orang tua, semisal, orang tua mampu menyisihkan uang 10.000 - 50.000 perbulan, dan dalam membeli buku juga harus 
disesuaikan dengan anggaran yang ada. Dalam hal ini menyisihkan uang untuk membeli buku membutuhkan komitmen, kedisiplinan, dan kerelaan. Karena dalam hal ini bagi keluarga yang tidak memiliki unsur kerelaan dan komitmen yang tinggi akan tergoyahkan dan mengaggap bahwa berbelanja seperti baju-celana dan kebutuhan yang lain jauh lebih bermanfaat dari pada membeli buku. Maka disini dibutuhkan komitmen orang tua, seta anggapan bahwa buku sebenarnya merupakan investi untuk anak di masa depan.

f. Menonton film dan membeli bukunya

Untuk memotivasi anak supaya gemar membaca buku orang tua bisa mengajak anak menonton film yang sekaligus disitu sudah terdapat bukunya kemudian anak dan orang membaca bukunya serta memcocokkan dengan isi film. Cara ini akan membuat anak antusias dan menyukai bukubuku tersebut. Misalnya menonton film Nemo dan bukunya yang berkisah tentang seekor ikan kecil, Lion King, Donald Bebek, Upin Ipin dan sebagainya.

g. Menciptakan perpustakaan keluarga

Membuat perpustakaan keluarga di rumah adalah langkah yang baik untuk membiasakan anak membaca buku. Perpustakaan tidak harus mewah dan memiliki koleksi buku yang banyak. Melainkan cukup dengan membuat ruangan khusus yang di situ di lengkapi dengan berbagai macam koleksi buku yang disukai anak. Selain itu, seyogyanya orang tua menempatkan buku pada tempat yang mudah dijangkau oleh anak seperti lemari kecil, meja, dan sejenisnya yang akan memudahkan anak untuk mengambil buku-buku tersebut.

h. Menukar buku milik anak dengan buku temannya

Semakin bayak buku yang dimiliki anak akan semakin baik, tetapi harga buku juga semakin mahal. Untuk menyiasatinya adalah dengan cara saling bertukar buku kepada teman sesuai dengan usianya. Orang tuanya hendaknya memberikan nasehat kepada anak bahwa saling meminjamkan buku akan memberi manfaat kepada orang lain dan diri sendiri, karena buku yang sudah pernah dibaca oleh anak dapat dimanfaatkan kembali oleh temannya, sementara temannya yang mempunyai koleksi buku baru dapat dimanfaatkan oleh anak, selain menukar buku dengan temannya yang perlu diperhatikan di sini adalah tetap menjaga kebersihan dan keutuhan buku, karena semakin banyak buku dipegang dan semakin sering buku dibaca maka akan berpengaruh pada bentuk serta keindahan buku itu sendiri. 
i. Menghilangkan penghambat seperti TV dan Playstation

Orang tua bertanggung jawab mengendalikan kebiasaan anak menonton TV dan bermain playstation. Di sini orang tua tidak harus melarang anak untuk menonton TV maupun bermain playstation, namun orang tua cukup memberikan jadwal kepada anak dimana waktu harus menonton TV serta bermain playstation, dan dimana waktu untuk membaca buku, dengan hal ini maka anak akan merasa bertanggung jawab dengan jadwal yang telah disepakati, serta orang tua juga tidak terkesan merampas hak anak untuk merefleksikan fikirannya melalui kegiatan menonton TV dan bermain playstation.

j. Memberi reward memperbesar semangat membaca

Untuk bisa merangsang minat baca anak maka cara yang dapat ditempuh orang tua salah satunya adalah dengan membarikan penghargaan baik bersifat materi maupun non materi. Jika sudah selesai membaca buku dan menceritakan kembali buku itu maka orang tua bisa memberikan pujian dengan kata-kata postif kepada anak, sehingga anak akan merasa sangat percaya diri dalam membaca buku, dan tumbuh semangat untuk kembali memperbayak dalam membaca buku.

k. Menjadikan buku sebagai reward untuk anak

Jika anak berulang tahun atau jika ada event-event tertentu dimana orang tua ingin memberikan suatu kado untuk anak, maka orang tua dianjurkan untuk memilih buku sebagai hadiah. Jadikan buku sebagai suatu barang yang berharga yang dinanti-nantikan oleh anak.

1. Menjadikan kegiatan membaca sebagai kegiatan setiap hari

Kegiatan membaca setiap hari akan menumbuhkan minat baca anak dan membentuk reading habit-nya jalan kearah kesukaan sudah terbuka karena ilmu dimulai dengan membaca sebagai suatu kegiatan yang menyenangkan antara orang tua dan anak. Agar terciptanya harapan tersebut, maka orang tua dianjurkan untuk memberikan jadwal khusus membaca kepada anak.

m. Mendramatisasi buku yang dibaca

Jika anak kurang tertarik dengan buku yang dibacakan untuknya, maka ubahlah cara bacanya dengan cara menambahkan kosa kata dan kalimat yang lebih menarik serta dramatisasi cerita dengan menambahkan gerak tubuh, mimik muka, dan intonasi suara. Dengan cara ini anak akan menjadi lebih antusias terhadap buku yang dibacakan, atau membaca buku secara mandiri.

148 n. Membuat buku sendiri. 
Anak akan merasa sangat senang jika orang tua membuat buku untuknya, seperti buku yang menceritakan tetang diri anak mulai dari lahir, kebiasaan yang dilakukan, makanan yang disukai, makanan yang tdak disukai dan lain sebagainya.

Sebagai alternatif lainnya orang tua juga dianjurkan untuk membuat buku yang menceritakan tentang dirinya sendiri di masa seusia dengan anaknya saat ini, yang berisi tentang hal-hal yangdisukai ataupun hal yang tidak disukai, kegiatan sehari-hari dan sejenisnya. Dengan membuat buku sendiri akan menjadikan anak merasa diistimewakan sehingga dengan sendirinya tumbuh kegemaran dalam membaca. Selain itu anak juga dapat menulis buku untuk dirinya sendiri dengan bahasanbahasan yang sederhana. (Ana Yulia. 2005; 51-75).

\section{Kesimpulan}

Kata intelegenci bersal data kata "intelegen" yang bermakna tajam pikiran, cerdas, cerdik, cendekia, bijaksana. Sementara intelegensi sendiri dimaknai sebagai kecerdasan atau ketajaman pikiran.

Sementara linguistic merupakan disiplin ilmu yang mempelajari bahasa secara luas dan umum. secara luas berarti cakupannya meliputi semua aspek dan komponen bahasa. Secara umum berarti sasarannya tidak hanya terbatas pada salah satu bahasa saja (misalnya bahasa Indonesia saja).

Dari kedua pengertian di atas sehingga berimplikasi bahwa yang dimaksud dengan Linguitic intelegency, merupakan kemampuan dan kepekaan seseorang dalam memaknai susunan kata, mampu menggunakan kata secara efektif, baik secara lisan maupun tertulis. Intelegensi pada jenis ini diidentifikasi oleh Gardner banyak terlibat dalam kegiatan membaca, menulis, berbicara, dan mendengar.

Adapun tujuan linguitic intelegency adalah. Pertama, anak mampu membaca serta memahami apa yang telah ia baca, kedua, anak mampu mendengarkan dengan baik serta mampu memberikan respon berbentuk komunikasi secara lisan, ketiga, anak mampu menirukan suara, mampu mempelajarai bahasa asing, dan mampu membaca karya orang lain, keempat, anak mampu menulis dan berbicara secara efektif dan tertarik pada karyakarya jurnalistik, berdiplomasi, mampu bercerita, serta melakukan kegiatan editing pada karya tulis orang lain, kelima, mampu belajar melalui apa yang ia dengar, tulisan, dan berdiskusi.

Kemampuan membaca anak dipengaruhi oleh beberapa faktor diantaranya 1) kefasihan dalam membaca, 2) kemampuan dalam mendengar, 149 
3)kemampuan melihat, 4) pengaruh lingkungan, 5) faktor emosi, dan 6) kecerdasan anak.

Beberapa faktor diatas sehingga menjadi pengaruh dalam kemampuan membaca anak, oleh karena itu, dalam hal ini kemampuan membaca anak perlu untuk ditingkatkan dengan berbagai macam cara, adapun cara yang dapat ditempuh adalah : 1) membacakan anak buku sejak lahir, 2) mendorong anak untuk bercerita tentang apa yang telah didengar atau dibacanya, 3) mengajak anak ke toko buku atau ke perpustakaan, 4) membeli buku yang menarik minat anak, 5) menyisihkan uang untuk membeli buku anak, 6) menyisihkan uang untuk membeli buku anak, 7) menonoton film serta membeli buku yang sesuai dengan film, 8) menciptakan perpustakaan keluarga di rumah, 9) menukar buku milik anak dengan milik temannya, 10) menghilangkan penghambat seperti TV dan Playstation, 11) memberi reward memperbesar semangat membaca anak, 12) menjadikan buku sebagai reward untuk anak, 13) menjadikan kegiatan membaca sebagai kegiatan setiap hari, 14) mendramatisasi isi buku yang dibacakan untuk anak, dan 15) membuat buku sendiri. 


\section{DAFTAR PUSTAKA}

\section{Buku}

Ana Yulia. 2005 . Cara Menumbuhkan Minat Baca Anak. PT Elex Media Komputindo. Jakarta.

Fahim Musthafa. 2005. Agar Anak Anda Gemar membaca.PT Hikmah. Bandung. Cetakan I.

Henri Guntur Targan. 2008. Membaca sebagai Suatu Ketrampilan Berbahasa. PT Angkasa . Bandung. Edisi Revisi.

Pius Partanto dan M. Dahlan Al Barry, 2001, Kamus Ilmiah Populer, Arkola, Surabaya.

Soeparno, 2002, Dasar-Dasar Linguistik Umum, Tiara Wacana, Yogyakarta. Soejono Dardjowidjojo, 2012, Psikologi Linguistik Pengantar Pemahaman Bahasa Manusia, Yayasan Pustaka Obor Indonesia, Jakarta.

\section{Website}

Id.wikipedia.org/wiki/Organisasi-pendidikan-keilmuan-dan kebudayaan.

Kompas/2015/08/21/Minat-baca-anak-masih-rendah,

Perpusnas.go.id/Majalah-Online/Perpustakaan-Nasional-RepublikIndonesia

Republika.co.id, diunduh pada 13 Nopember 2015.

www.putuputrayasa.com/jadi-penulis-inspiratif

www.Republika.co.id,menumbuhkan minat baca masyarakat 